\title{
Radyoterapiyi takiben kritik boyutta oluşturulan kemik defektlerinde antibiyotiklerin etkinliğinin deneysel olarak incelenmesi
}

\author{
Özgün Günay(0000-0001-6177-7268) ${ }^{\alpha}$, Özge Doğanay(0000-0001-5273-7774) $)^{\beta}$, Olgu Enis Tok(0000-0002-4899-9146) ${ }^{\nu}$, \\ Alper Alkan(0000-0002-7072-511X) ${ }^{\beta}$
}

Selcuk Dent J, 2020; 7: 294-303 (Doi: 10.15311/selcukdentj.695767)

Bašuru Tarihi: 29 Subat 2020 Yayına Kabul Tarihi: 06 Nisan 2020

öz

Radyoterapiyi takiben kritik boyutta oluşturulan kemik defektlerinde antibiyotiklerin etkinliğinin deneysel olarak incelenmesi

Amaç: Çenelerin osteoradyonekrozu (ORN), baş ve boyun kanserlerinde radyasyon tedavisinin bir komplikasyonu olarak karşımıza çıkmaktadır. Tanımı ve sınıflandırması yıllar içinde değişiklik göstermiş, patofizyolojisine dair teorileri geliştirilmiş ve buna bağı olarak farklı tedavi prensipleri denenmiştir. Çalışmadaki amacımız, radyoterapiyi takiben alt çene kemiğinde cerrahi olarak oluşturulan kritik boyuttaki defektlerde klindamisin, metronidazol, rifamisin ve doksisiklin grubu antibiyotiklerin kemik iyileşmesi üzerindeki etkilerini incelemektir.

Gereç ve Yöntem: Anti-enflamatuar etkinliğin kemik iyileşmesi üzerindeki etkilerini değerlendirmek için, 50 adet Wistar cinsi albino türü sıçanlar kullanılmıștır. Tüm gruplara genel anestezi altında 30 Gy dozda radyoterapi uygulandıktan 8 hafta sonra sıçanların sağ mandibulasında $5 \mathrm{~mm}$ çapında bikortikal hazırlanan kemik defektlerine deney gruplarında ksenogreft ile karıştırılan antibiyotikler, kontrol gruplarında ise sadece ksenogreft partikülleri uygulanarak cerrahi saha iyileşmeye bırakılmıştır. Sakrifikasyon sonrasında elde edilen örneklerde enflamasyon, nekroz, fibrozis, yeni kemik yapım alanı, kalsifiye olmuş kemik alanı ve kapiller sayısı histopatolojik ve histomorfometrik olarak değerlendirilmiştir.

Bulgular: Incelenen kesitlerde nekroz, enfeksiyon ya da fibrozis bulgusuna rastlanmamıştır. Kontrol grubu ile yapılan karşılaştırmalarda metronidazol ve klindamisin gruplarında yeni kemik yapım alanlarının anlamlı derecede yüksek olduğu görülmüştür $(p<0.01, p<0.01)$. Kalsifiye kemik trabekül alanları incelendiğinde kontrol grubu ile klindamisin grubu arasında istatistiksel olarak ileri derecede anlamlı fark tespit edilmiştir $(p<0.01)$. Klindamisin ile diğer gruplar karşılaştıııldığında ise aradaki fark anlamlı $(p<0.05)$ bulunmuştur. Kontrol grubu ile yapılan karşılaştırmalarda kapiller sayısı metronidazol grubunda anlamlı $(p<0.05)$, klindamisin grubunda $(p<0.01)$ ise ileri derecede anlamlı olarak farklı bulunmuştur.

Sonuç: Antibiyotik uygulanan gruplarda iltihabi alanların sayısında azalma, yeni kemik yapım alanlarında ve damarlanmada artış gözlenmiştir. Çalışmada kullandığımız antibiyotiklerin antibakteriyel aktiviteden bağımsız olarak anti-enflamatuar etkinliklerinin olabileceği düşünülmektedir.

\section{ANAHTAR KELIMELER}

Antibiyotik, anti-enflamatuar etki, kemik iyileşmesi, klindamisin, osteoradyonekroz, radyoterapi, sıçan

\section{ABSTRACT}

Experimental investigation of the efficiency of antibiotics in the critical size bone defects following radiotherapy

Background: Osteoradionecrosis of the jaws is a complication of radiation treatment for cancer of the head and neck. Its definition and classification have changed over the years and theories of its pathophysiology have evolved and led to new treatments. This study aimed to investigate the effects of clindamycin, metronidazole, rifamycin and doxycycline on bone healing in the surgically created critical size defects in the bone of lower jaw, following radiotherapy.

Methods: To investigate the effect of anti-inflammatory function on bone healing, 50 Wistar albino rats were used. Following radiotherapy, bicortical bony defects in $5 \mathrm{~mm}$ diameter was created in the right mandible of every rats, filled with antibiotics and xenograft in the experimental groups, and with only xenograft particles in the control groups. After sacrification period, all specimens were evaluated in terms of inflammation, necrosis, fibrosis, new bone formation areas, calcified trabecular bone areas and capillary count, histologically and histomorphometrically.

Results: None of the specimens showed symptoms of necrosis, infection or fibrosis. The new bone formation areas were significantly higher in metronidazole and clindamycin groups when compared with control group $(p<0.01, p<0.01)$. As the calcified bone trabecular areas were examined, there was a statistically significant difference between the control and clindamycin group ( $p$ $<0.01$ ). As the group of clindamycin was compared with other groups, the difference was also statistically significant $(p<0.05)$. The capillary count was significantly different in the groups of metronidazole $(p<0.05)$ and clindamycin when compared with the control group $(p<0.01)$.

Conclusion: Inflammatory reaction decreased in the groups treated with antibiotics, the areas of new bone formation and capillarity increased. Based on this study results, antibiotics might have anti- inflammatory activities independent of their antibacterial properties.

\section{KEYWORDS}

Antibiotic, anti-inflammatory effect, bone healing, clindamycin, osteoradionecrosis, radiotherapy, rat

\footnotetext{
${ }^{\alpha}$ Serbets Diş Hekimi, İstanbul

${ }^{\beta}$ Bezmialem Vakıf Üniversitesi Diş Hekimliği Fakültesi Ağız, Diş ve Çene Cerrahisi Anabilim Dalı, İstanbul, Türkiye

${ }^{\gamma}$ İstanbul Medipol Üniversitesi Tip Fakültesi Histoloji ve Embriyoloji Anabilim Dalı, İstanbul
} 
Çenelerin osteoradyonekrozu (ORN), baş ve boyun kanserleri için uygulanan radyasyon tedavisinin bir komplikasyonu olarak ortaya çıkmıştır. Kemiğin radyasyona maruz kalması sistemik ve lokal faktörlere cevap veren normal fizyolojik mekanizmaları değiştirmekte, ve çenelerin bütünlüğünün ve sağlığının sürdürülmesindeki fonksiyon kaybedilmektedir. ORN' nin tanımı ve sınıflandırması yıllar içinde değişiklik göstermiş, ${ }^{1,2}$ ve çene osteonekrozu ile ilgili yeni tedavi alternatifleri gündeme gelmiştir. ${ }^{3}$

Baş-boyun bölgesinden radyoterapi almış hastalarda çenelerde osteoradyonekroz gelişimini önlemek, enfeksiyona olan yatkınlığı azaltmak, damarlanması kötü olan dokuları sınırlandırmak ya da semptomları azaltmak için farklı yaklaşımlar ve tedavi protokolleri önerilmiştir. ${ }^{4}$ Radyoterapi sonrasında dokunun rejenerasyon kapasitesini arttırmak amacıyla enflamasyonu baskılayarak iyileşmeyi desteklemek ve/veya enfeksiyöz tablonun gelişimini önlemek için kullanılan tedavi protokolleri tıbbın her alanında olduğu gibi ağız diş ve çene cerrahisi pratiğinde de sıklıkta kullanılmaktadır. ${ }^{5}$

İnflamasyonun baskılanması ile dokudaki ödem gerilemekte ve kemikteki iyileşme süreci hızlanmaktadır. ${ }^{6}$ Bu amaç için çeşitli tedavi yöntemleri ve ajanlar kullanılmaktadır. Bunlar arasında hiperbarik oksijen tedavisinin vazokonstrüktif etki ile inflamasyonu azalttığı ve buna bağlı olarak kemik iyileşme sürecini desteklediği düşünülmektedir. ${ }^{7}$ Ancak, HBO'nun her hasta grubuna uygulanamaması ya da etkili olmaması gibi olumsuz yönleri, alternatif tedavi yöntemlerinin geliştirilmesine neden olmuştur. Anti-inflamatuar etki gösteren diğer ajanların osteonekroz profilaksisinde kullanılabilirlikleri halen araştırımaktadır. Günümüzde antibiyotikler terapötik ya da profilaktik nedenlerle mikroorganizmaları inaktive etmek ya da ortadan kaldırmak için kullanılan ajanlardır. Ancak, bilinen bakterisit ve bakteriyostatik etkilerine ilave olarak, diğer biyolojik, fizyolojik ve çeşitli konak savunma mekanizmaları üzerinde önemli immünolojik özellikleri de bulunmaktadır. ${ }^{8}$

Antibiyotiklerin antibakteriyel özellikleri dışında gösterdikleri anti-inflamatuar etkinlik ile de kemik iyileşmesini olumlu yönde etkiledikleri düşünülmektedir. ${ }^{9}$ Son dönemde yapılan çalışmalarda, bazı antibiyotiklerin anti-inflamatuar etkinliklerinin olduğu ve kemik iyileşmesini hızlandırdığı yönünde veriler yer almaktadır, ancak çene cerrahisi pratiğinde sıklıkla kullanılan antibiyotiklerin enflamasyonla ilişkili kemik iyileşme süreci üzerindeki etkileri henüz bilinmemektedir. ${ }^{10} \mathrm{Bu}$ sebeple, çalışmamızda, radyasyona maruz kalmış alt çene kemiğinde cerrahi olarak oluşturulan kritik boyuttaki kemik defektlerine doksisiklin, rifamisin, metronidazol ve klindamisin grubu antibiyotikleri lokal olarak uygulayarak kemik iyileşmesi üzerindeki etkileri incelemeyi amaçladık.

\section{GEREÇ VE YÖNTEM}

$\mathrm{Bu}$ proje kapsamındaki hayvan deneyleri için, Bezmialem Vakıf Üniversitesi Deney Hayvanları Yerel Etik Kurulu' nun 20/07/2017 tarih ve 2017/194 sayılı kararı ile onay alınmıştır. Çalışmamız, 50 adet wistar cinsi albino türü , 250ะ 20 gr ağırlığında ve 10-12 haftalık dişi sıçanlar üzerinde yürütülmüştür. Sıçanlar rastgele 4 farklı antibiyotik çeşidine göre deneysel ve 1 adet kontrol olmak üzere 5 gruba (n:10) ayrılmıştır. Çalışmada kullanılan materyaller Tablo 1' de verilmiştir.

Tablo 1.

Kontrol ve deney gruplarının örneklerinin diş çekim bölgelerinin klinik olarak değerlendirilmesi

\begin{tabular}{|llll|}
\hline Materyal & Marka & Kullanım şekli & Firma \\
\hline Doksisiklin & Tetradox & $100 \mathrm{mg}$ kapsül & Actavis - ABD \\
\hline Rifamisin & Rifetem & $250 \mathrm{mg}$ IM ampul & Ulagay-Türkiye \\
\hline Metronidazol & Neofleks & $100 \mathrm{ml} \mathrm{IV} \mathrm{ampul}$ & Türktıpsan-Türkiye \\
\hline Klindamisin & Klindan & $600 \mathrm{mg}$ ampul & Bilim-Türkiye \\
\hline Ksenogreft & Bio-Oss & $\begin{array}{l}0,25-1 \mathrm{~mm} \\
\text { partikül }\end{array}$ & $\begin{array}{l}\text { Geistlich Söhne AG- } \\
\text { İviçre }\end{array}$ \\
\hline
\end{tabular}

\section{Deney Grupları (n:40):}

Klindamisin grubu (Grup KL) (n:10), Doksisiklin grubu (Grup D) (n:10), Rifamisin grubu (Grup R) (n:10), Metronidazol grubu (Grup M) (n:10): Başboyun bölgesinden radyoterapi almış sıçanların sağ mandibulalarında kritik boyutta oluşturulan kemik defektine kemik grefti ile beraber bulunduğu gruptaki bir antibiyotik karıştırılarak defekt onarımı yapıldı.

Kontrol grubu (Grup KO) (n:10): Baş-boyun bölgesinden radyoterapi almış sıçanların sağ mandibulalarında kritik boyutta oluşturulan kemik defektine kemik grefti yerleştirilerek iyileşmeye bırakıldı.

\section{Radyoterapi uygulaması}

Genel anestezi altında sıçanların baş-boyun bölgesine tek doz radyoterapi uygulaması yapıldı. Sıçanlar; Cobalt 60 (Teletherapy Equipments ALCYON CYRUS) cihazına alınarak üzerlerine $1,5 \mathrm{~cm}$ kalınlığındaki Bolus materyali yerleştirildi. Cihaz uzaklığı kaynak-cilt mesafesi (SSD) $98,5 \mathrm{~cm}$ olacak şekilde belirlendi. Işın alanı izosentrda $30 \times 4 \mathrm{~cm}^{2}$ olacak şekilde açıldı ve sıçanların ışınlama bölgeleri ayarlandı. Lineer hızlandırıcı, hesaplamaları sonucu 30 Gy' e karşlık gelen 1900 Monitor Unit verecek şekilde $6 \mathrm{MV}$ enerjili X-ışını verildi. Radyoterapinin kemik üzerindeki etkilerinin görülebilmesi için ışınlamadan 8 hafta sonra cerrahi işlemler gerçekleştirilmiştir.

\section{Cerrahi uygulama}

Sıçanlara $50 \mathrm{mg} / \mathrm{kg}$ Ketamin HCL ve $10 \mathrm{mg} / \mathrm{kg}$ i.m. Xylazin HCL karışımının periton içine uygulanması ile genel anestezi altında cerrahi ișlemler gerçekleștirildi. 
Mandibulanın angulus bölgesinde bazisin $1 \mathrm{~cm}$ altından olacak s,ekilde insizyon yapılarak kemik yüzeyi açığa çıkartıldı. Hayvanların post-operatif bakımları ve yașam kaliteleri düșünülerek sıçanların sağ mandibulalarında tek taraflı, $5 \mathrm{~mm}$ çapında trefin frez ile bikortikal kemik parçası çıkartılarak defekt sahası oluşturuldu. Bölgede hemostaz sağlandıktan sonra defektlerin üzerlerine gruplarda belirtildiği şekilde tek tip antibiyotik ile karıştırımış ksenogreftler uygulandı. Cilt ve cilt-altı dokular orjinal konumlarına getirilerek poliglaktin 910 (Vicryl, Ethicon, Amerika) dikiş materyali ile kapatılı.

Deneklerin genel saglık durumları, belirlenmiş sakrifikasyon dönemlerine kadar günlük kontrol edildi. Sıçanlar, 28. günde yüksek doz anestezik madde (Sodyum pentotal $120 \mathrm{mg} / \mathrm{kg}$ ) enjeksiyonu ile sakrifiye edildi. Sakrifikasyon isșlemleri sonrasında sıçanların kemik defektini içeren sağ mandibuler segmentleri çıkartılarak \%10'luk nötral formaldehit çözeltisi içerine yerleştirildi.

\section{Histolojik ve histomorfometrik değerlendirme}

Sıçanlardan alınan kemik örnekleri \%10'luk nötral tamponlu formalin içerisinde fikse edildikten sonra $10 \%$ EDTA ile dekalsifiye edildi. Daha sonra distile su ile yıkanıp yükselen alkol serisi $(70 \%, 90 \%, 96 \%$ ve $100 \%)$ ve ksilenden geçirilerek parafin içerisine gömülerek bloklandı. Hazırlanan bloklardan mikrotom ile $5 \mu \mathrm{m}$ kalınlıkta kesitler pozitif şarjlı lamlar üzerine alındı. Kesitler histolojik ve histomorfometrik analizler için hematoksilin ve eosin (H\&E) ile boyandı. Boyanan kesitler Nikon DS-Fi1c (Tokyo, Japonya) kamera ataçmanlı Nikon Eclipse i5 (Tokyo, Japonya) ışık mikroskobu ve NIS Elements sürüm 4.0 görüntü analiz sistemi (Nikon Instruments Inc, Tokyo, Japonya) ile incelenip görüntülendi. Tüm gruplarda defekt bölgesindeki enflamasyon, nekroz, fibrozis, yeni kemik yapım alanları, kapiller sayımı, kalsifiye kemik yapımı alanları histopatolojik ve histomorfometrik olarak değerlendirildi. Histomorfometrik ölçümler her örnekten $200 \mu \mathrm{m}$ aralıklarla alınan 3 seri kesitte yapılıp ortalamaları alınarak hesaplandı.

\section{İstatistiksel değerlendirme}

İstatistiksel analizler Graph-Pad Prism 5.0 (GraphPad Software, San Diego, CA, USA) programı kullanılarak yapıldı. Gruplar arası karşılaştırmalarda Kruskal Wallis ve MannWhitney $U$ testi kullanıldı. $p<0.05$ anlamlı olarak kabul edildi.

\section{BULGULAR}

\section{Makroskopik bulgular}

Sıçanlarda operasyona ikincil gelișen yara yeri enfeksiyonu, deri nekrozu, ülserasyon, kıl dönmesi ya da bașka bir komplikasyon görülmedi.

\section{Mikroskopik bulgular}

Kesitlerde nekroz, enfeksiyon ya da fibrozis oluşumuna ait herhangi bir bulguya rastlanmamıştır. Mandibulada oluşturulan bikortikal kemik defektlerinde greft uygulaması sonrasında hemen hemen tüm gruplara ait örneklerde defektin inflamatuar hücrelerden zengin bağ dokusu içerdiği görülmüştür. Kesitlerin çoğunda defektin üzerinde fibröz bağ dokusu alanları izlenmiştir. Sadece greft uygulanan kontrol ve greft+doksisiklin uygulanan gruplarda 3 örnekte ve rifamisin grubunda 2 örnekte defekt alanının yaklaşık \%70'inin kapandığı gözlenmiştir.

Kontrol grubunda defekt bölgesinin yoğun inflamatuar hücrelerden zengin bağ dokusu ile kaplandığı, bu bölgede çok sayıda greft partiküllerinin bulunduğu ve defektin periferinde az sayıda kalsifiye olmuş kemik trabekülleri olduğu gözlenmiştir (Şekil 1).

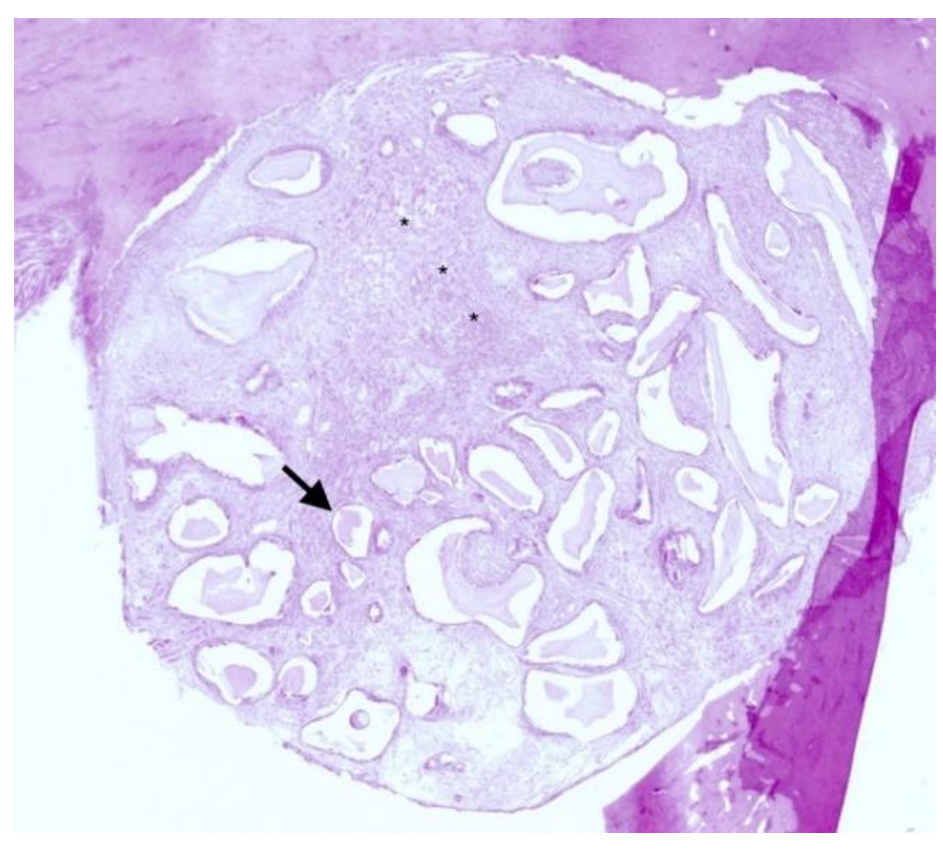

Şekil 1.

Kontrol grubunda defekt bölgesindeki kemik iyileșmesinin histolojik olarak incelenmesi. Greft partikülleri (ok), defekt bölgesinde yoğun enflamatuar bağ dokusu hücreleri (*) görülmektedir (H\&E x 100)

Doksisiklin grubunda defekt bölgesinde benzer olarak yoğun enflamatuar hücrelerden zengin bağ dokusu ve defekt bölgesinin periferinden başlayıp merkeze doğru uzanan greft partikülleri ile birlikte defektin periferinde az sayıda kalsifiye olmuş kemik trabekülleri gözlenmiştir (Şekil 2). 


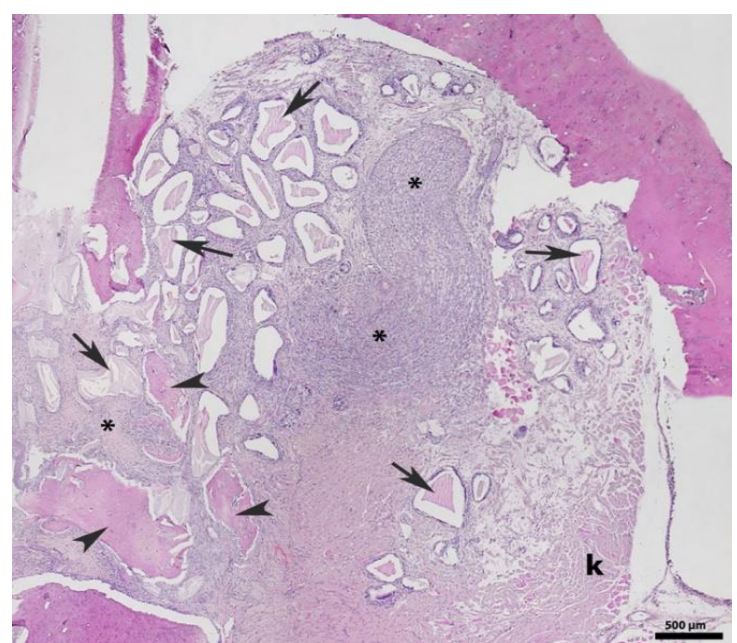

Şekil 2.

Doksisiklin grubunda defekt bölgesindeki kemik rejenerasyonunun histolojik olarak incelenmesi. Periferde oluşmaya başlayan kemik trabekülleri (ok başı), defektin merkezinde ve kenarlarda greft partikülleri (ok), defekt içerisinde ise yaygın olarak enflamatuar bağ dokusu hücreleri $(*)$ izlenmektedir (H\&E x 100)

Rifamisin grubunda kalsifiye olan kemik trabeküllerinin yoğunluğu düşük olmakla birlikte kalsifiye olmamış kemik miktarında çok az artış bulunmaktadır. Defekt bölgesinde greft partikülleri izlenmektedir. Kalsifiye olmuş kemik trabekülleri ise genellikle defekt bölgesinin periferinde olmakla birlikte bazı kesitlerde merkeze yakın yerlerde de gözlenmiştir (Şekil 3).

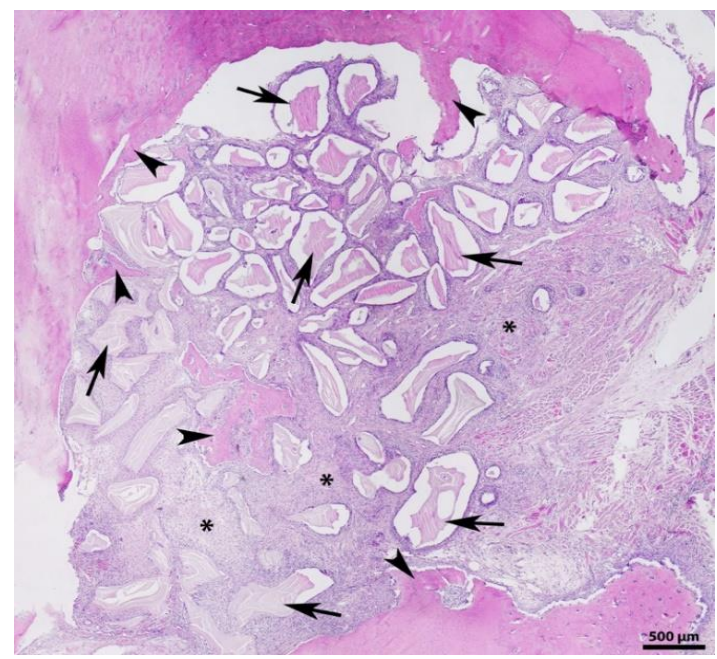

Şekil 3.

Rifamisin grubunda kemik rejenerasyonunun histolojik olarak incelenmesi. Periferde ve merkezde oluşan kemik trabekülleri (ok başı), greft partikülleri (ok) ve yoğun enflamatuar hücrelerden zengin bağ dokusu $\left(^{*}\right)$ alanları izlenmektedir (H\&E x 100)

Metronidazol grubunda defekt bölgesinin periferinde yeni oluşan kemik trabekülleri yoğun olarak, defektin merkezinde ise az miktarlarda, greft partikülleri ise defekt alanının her bölgesinde yoğun olarak izlenmektedir. Total kemik rejenerasyon alanlarının, kontrol ve doksisiklin gruplarına göre daha fazla olduğu tespit edilmiştir (Şekil 4).

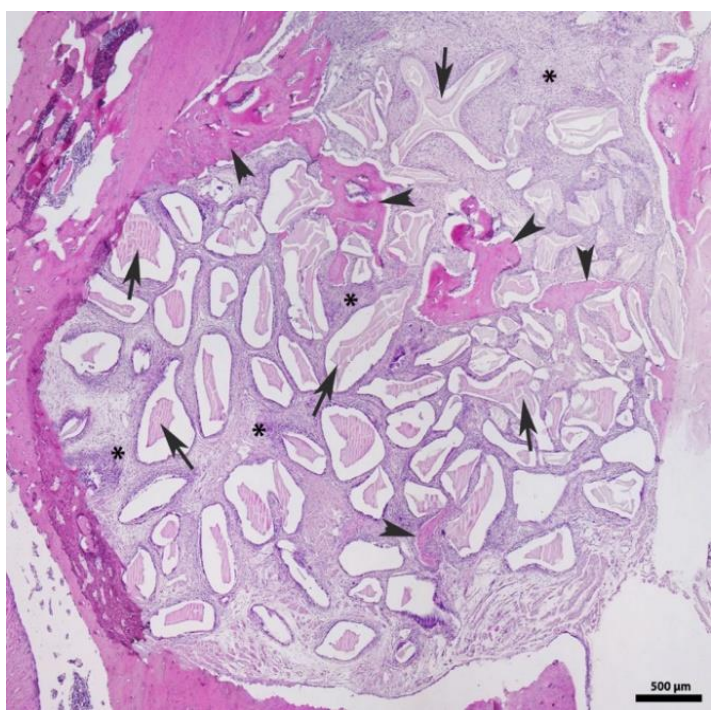

Şekil 4.

Metronidazol grubunda kemik rejenerasyonunun histolojik olarak incelenmesi. Kemik defektinin her yerinde eșit miktarlarda kemik trabekülleri (ok başı), greft partikülleri (ok) ve enflamatuar hücrelerden zengin bağ dokusu $(*)$ alanları görülmektedir (H\&E x 100)

Klindamisin grubunda kalsifiye olmuş kemik trabeküllerinin oluşturduğu alanlar çoğunlukla perifer, az miktarda merkezde olmak üzere diğer grupların neredeyse iki katı kadar artmış ve yeni kemikleşen bölgelerin etrafında ise greft partikülleri ve greftin çevresinde ise enflamatuar hücrelerden zengin bağ dokusu alanları görülmektedir. Total kemik rejenerasyon alanları rifamisin ve metronidazol grubu ile aynı oranlarda olmasına rağmen kalsifiye kemik trabekülü alanlarının daha fazla olduğu tespit edilmiştir (Şekil 5).

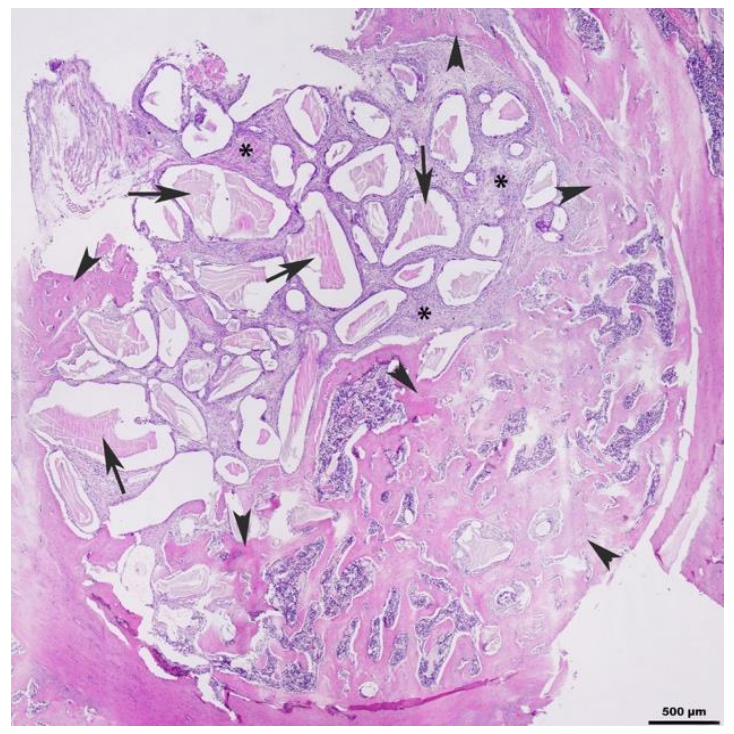

Şekil 5.

Klindamisin grubunda kemik rejenerasyonunun histolojik olarak incelenmesi. Yeni oluşan kemik trabekül miktarının (ok başı) defekt bölgesinde kapladığı alanın artışı, greft partiküllerinin (ok) dağılımı ve paralel olarak enflamatuar hücrelerden zengin bağ dokusu (*) miktarında belirgin azalma olduğu görülmektedir (H\&E x 100). 
Yeni oluşan kemik yapımı alan ölçümü yüzdesel olarak değerlendirildiğinde; metronidazol ve klindamisin gruplarının kontrol grubundan istatiksel olarak anlamlı derecede yüksek olduğu görüldü $(p<0.01)$ (Tablo 2).

Defekt bölgesinde kalsifiye olmuş kemik trabeküllerinin alan ölçümü yüzdesel olarak incelendiğinde; kalsifiye kemik trabeküllerinin alanı doksisiklin, rifamisin ve metronidazol gruplarında kontrol grubuna göre istatistiksel derecede anlamlı olmayan bir artış gösterdi. Klindamisin grubunda ise kontrol grubuna kıyasla gözlemlenen artı̧ istatistiksel olarak ileri derecede anlamlı $(p<0.01)$, diğer gruplar ile karşılaştırıldığında ise anlamlı $(p<0.05)$ bulundu (Tablo 2$)$.

Kapiller sayısı, kontrol, doksisiklin ve rifamisin gruplarıyla karşılaştııılı̆̆ında anlamlı farklıık bulunmazken, metronidazol grubuyla olan fark istatistiksel olarak anlamlı $(p<0.05)$ ve klindamisin grubuyla $(p<0.01)$ olan fark ise istatiksel olarak ileri derecede anlamlı bulundu (Tablo 2) .

\section{Tablo 2.}

\section{Tüm grupların histopatolojik ve histomorfometrik değerlendirme sonuçları}

\begin{tabular}{|c|c|c|c|c|c|}
\hline & Kontrol & Doksisiklin & Rifamisin & Metronidazol & Klindamisin \\
\hline $\begin{array}{l}\text { Total } \\
\text { kemikleşme } \\
\text { alanları (\%) }\end{array}$ & $13 \pm 2,7$ & $14,3 \pm 10,8$ & $22 \pm 10$ & $\begin{array}{l}23,6 \pm 8,5 \\
\star *\end{array}$ & $\underset{\star \star}{22,4} \pm 5,5$ \\
\hline $\begin{array}{l}\text { Kalsifiye } \\
\text { kemikleşme } \\
\text { alanları (\%) }\end{array}$ & $6,9 \pm 4$ & $\begin{array}{l}10,9 \pm 10,9 \\
+\end{array}$ & $\begin{array}{l}11,3 \pm 8,1 \\
+\end{array}$ & $\begin{array}{l}11 \pm 9,5 \\
+\end{array}$ & $\underset{\star *}{19,6 \pm 4,6}$ \\
\hline $\begin{array}{l}\text { Kapiller } \\
\text { sayısı }\end{array}$ & $2 \pm 0,8$ & $2,7 \pm 1,7$ & $2,8 \pm 1,4$ & $\begin{array}{l}3,4 \pm 1 \\
*\end{array}$ & $\begin{array}{l}4 \pm 1,3 \\
\star *\end{array}$ \\
\hline
\end{tabular}

\section{TARTIŞMA}

Çenelerde görülen osteoradyonekroz, halen radyoterapinin en yaygın görülen komplikasyonudur. ${ }^{11}$ Bununla birlikte, en sık bildirilen etken radyasyon arteritidir. Radyasyon arteriti, patolojik durumlara yol açan hipoküler, hipovasküler ve hipoksik bir ortamın gelişmesine neden olarak kemiğin iyileşme sürecini baskılamaktadır. ORN gelişimindeki predispozan faktörler, klinik sınıflama, hastalığın prognozu ve tedavi protokolleri hala araştırımaktadır. ${ }^{12,13}$

ORN sıklığı literatürde \%0.4-\%56 değişen oranlarda farklılıklar göstermektedir. ${ }^{14-17}$ Ancak, en yaygın bildirilen gelişim sıklığı \%5-15 arasındadır. ${ }^{18-20}$ ORN prevalansı 1990' lardan bu yana düşüş göstermektedir. ${ }^{21}$ Son çalışmalar ORN sıklığının \% 5'in altına düştüğünü rapor etmiştir. ${ }^{22} \mathrm{Bu}$ düşüş, radyoterapi tekniklerinin geliştirilmesine, ağız hijyen düzeyinin yükseltilmesine, enfeksiyonun ve enflamasyonun kontrol altına alınmasına bağlanmaktadır. ${ }^{12,23}$ Kötü ağız hijyeni; artan çürük sıklığı, periodontal hastalıklar ve bunun sonucunda lokal enflamasyonda ve dokudaki enfeksiyon riskinde bir artışa neden olur. ${ }^{24} \mathrm{Her}$ ne kadar iyi bir ağız bakımı hedef olsa da, dişin ve çevre dokuların sağlığı zamanla bozulabilir ve radyasyon uygulamasından aylar ya da yıllar sonra dişin alınması gerekebilir. Dentoalveoler girişimler, ışınlanmış çenelerde ORN gelişimine en sık neden olan faktörler arasında gösterilmektedir. Işınlama sonrasında ORN riskini azaltmak için kullanılan metodların etkinliği henüz araştırma aşamasındadır. ${ }^{25}$ ORN'de tedavi yaklaşımları, hastalığın safhasına, antibiyotiklerin kullanımına ve ağız hijyen düzeyinin iyileştirilmesi gibi konservatif tedavi seçeneklerine göre değişkenlik gösterebilmektedir. ${ }^{26,27}$

Delanian ve Lefaix ${ }^{28}$ ORN' nin, serbest radikal oluşumu, endotel disfonksiyonu, inflamasyon, mikrovasküler tromboz, fibroz, yeniden şekillenme, kemik ve doku nekrozu gibi radyasyona bağlı fibroatrofik bir mekanizma nedeniyle ortaya çıktığını ileri sürmüştür. Hücresel ve moleküler biyolojideki son gelişmeler, mikroskobik olarak gözlenen ORN' nin ilerlemesini daha iyi açıklamakta ve radyasyon ile indüklenen fibrozis teorisini desteklemektedir. Önerilen bu mekanizmada; başlangıç pre-fibrotik fazında eşlik eden akut enflamatuar cevap ile beraber başlıca endotel hücrelerinin hakimiyeti görülmektedir. Moleküler düzeyde ORN hastalığı sürecine odaklanan bu araştırmalar, yeni potansiyel tedavi seçeneklerinin hedeflerinin geliştirilmesine neden olmuştur. Buna bağlı olarak, öncelikle farmakolojik yöntemlerin denendiği yeni tedavi alternatifleri üzerinde araştırmalar yapılmaktadır. ${ }^{29,30,31}$

Terapötik ya da profilaktik nedenlerle kullanılan antibiyotikler, mikroorganizmalar üzerindeki bilinen bakterisit ve bakteriyostatik etkilerine ek olarak, diğer biyolojik, fizyolojik ve çeşitli konak savunma mekanizmaları üzerinde de önemli immünolojik özellikleri barındırmaktadır. ${ }^{8}$

Antibiyotiklerin anti-enflamatuar etkinlikleri ile ilgili yapılan çalışmalarda makrolid grubu antibiyotiklerin ve tetrasiklinlerin antibakteriyel etkinliklerinden bağımsız olarak iyileşmeyi desteklediği gösterilmiştir. ${ }^{32,33}$ lanaro ve ark. ${ }^{34}$, makrolid grubu antibiyotiklerin, pro-enflamatuar mediatörlerin ve sitokinlerin salınımını önleme yetenekleri ile bağlantılı olarak anti-enflamatuar aktivite gösterdiğini ve bu ajanlardan, özellikle roksitromisinin, anti-bakteriyel aktiviteden bağımsız olarak terapötik etkiler sergilediğini göstermiştir. ${ }^{35}$ Tetrasiklinlerin anti-enflamatuar etkisi antibakteriyel olmayan bir mekanizma ile ilişkilendirilmektedir. Siklin grubunun fagositoz fonksiyonları üzerindeki inhibitör etkilerinin klinik önemi de oldukça fazladır. Tetrasiklinlerin propionibacterium acnes proliferasyonunu inhibe ederek ve reaktif oksijen türlerinin (ROS) 
polimorf-nüveli lökositlerden salınmasını engelleyerek anti-enflamatuar etkinlik sağladığı yönünde de veriler bulunmaktadır. Bu özelliği sebebiyle, klinik pratiğinde enflamatuar akne tedavisinde de yaygın olarak kullanılmaktadır. ${ }^{36}$ Antikanserojen etki gösteren ve benzokinon ansamisin grubunda yer alan diğer bir ajan geldanamisinin ise in-vivo modellerde, akciğer enflamasyonunu ve akut akciğer hasarını hafiflettiği ve anti-enflamatuar etkinliğinin olduğu gösterilmiştir. ${ }^{32}$

Antibiyotiklerin kan ve kemikteki konsantrasyonlarının incelendiği çalışmalarda kan, skapula ve femur kemiğinden alınan örneklerde klindamisin konsantrasyonunun diğer antibiyotiklere oranla daha yüksek olduğu bildirilmiştir. ${ }^{37,38} \mathrm{Ek}$ olarak, kemiğe yönelik enfeksiyonlarda sıklıkla tercih edilen antibiyotiklerden biri olan klindamisinin, kemikten izole edilen konsantrasyonlarının diğer antibiyotiklere oranla daha yüksek olduğu gösterilmiştir. ${ }^{39}$ Yeni kemik yapım alanları ve kapiller sayısı incelendiğinde klindamisin grubunda enflamasyon bulgularının belirgin olarak azaldığı ve beraberinde kemikleşmenin arttığı tespit edilmiştir. Çalışmada kullandığımız klindamisin grubu antibiyotiğin, enflamasyonu azaltma ve iyileşme sürecini hızlandırmada en etkili ajan olduğu tespit edilmiştir. Antibiyotiklerin antibakteriyel olma dışındaki özellikleri ile kemik iyileşmesi arasındaki ilişki henüz bilinmemektedir. Ancak, farklı modellerde farklı tekniklerin uygulandığı çalışmalarda kemiğe en iyi geçiş yapan ajanın klindamisin olması ve kemik iyileşmesini hızlandırdığının gösterilmesi çalışmamızın sonuçlarını destekler niteliktedir.

Histopatolojik kesitler incelendiğinde, kemik ya da çevresindeki yumuşak dokulara ait nekroz ya da enfeksiyon bulgusuna rastlanmamıştır. Ancak, tüm gruplardaki kesitler incelendiğinde değişen derecelerde iltihabi bağ dokusu alanları dikkat çekmektedir. Bu durum, radyoterapiye bağlı yapısal değişikliklerin meydana geldiği kemikte onarım devam ederken cerrahi müdahale ile ek bir travma oluşturulması ve buna bağlı olarak, halen iyileşmekte olan yara dokusuna ait bulguların kesitlerde görülmesi ile açıklanmaktadır. Ek olarak, kontrol grubunda, antibiyotik uygulanan gruplara göre enflamasyon bulgularının daha yoğun olarak seyredilmesi, antibiyotiklerin radyasyon ışınlamasına maruz kalan kemikte anti-enflamatuar etkinliğinin olduğunu düşündürmektedir.

Özer ve ark. ${ }^{40}$ sıçan mandibulasında kritik boyuttaki defektlere ksenogreft ile rifamisin ve doksisiklin karışımını lokal olarak uygulayarak yeni kemik yapım alanlarını karşılaştırmış, ve rifamisin grubunun doksisiklinden daha başarılı olduğunu tespit etmişlerdir. Benzer olarak çalışmamızda rifamisin grubunda yeni kemik yapım alanları doksisiklin grubundan daha yüksek bulunmuştur, ancak aradaki fark anlamlı değildir. Gruplardaki kemik iyileşmesinin her iki grupta da geciktiği ve anti-enflamatuar etkinliğin belirgin olmadığı düşünülmektedir. Tüm gruplar incelendiğinde deney gruplarında iltihabi alanların sayısında azalma, yeni kemik yapım alanlarında ve damarlanma sayısında görülen artış, antibiyotiklerin antibakteriyel özelliklerinden bağımsı olarak enflamasyonu baskıladığını düşündürmektedir.

Radyoterapi dozu, dentoalveolar cerrahi ve kötü ağız hijyeni gibi hazırlayıcı faktörlerin osteonekroz insidansını arttırdığı bilinmektedir. ${ }^{41}$ Reuther ve ark. ${ }^{42}$ hastaların aldıkları toplam radyasyon dozunun ortalama 60 Gy üzerinde seyrettiği durumlarda ORN'nin gelişmeyebileceğini ancak eşlik eden hazırlayıcı faktörlerin varlığında ORN görülme intimalinin artacağını bildirmiştir. ${ }^{43,44}$ ORN, spontan ya da travma ile, enfeksiyon nedeniyle lokal damarlanması bozulan dokuda, komorbid hastalığı olan ve özellikle ileri yaş gruplarında, en az 60 Gy radyasyon dozunda ortaya çıkmaktadır. ${ }^{45,46}$

Sıçan modelinde ise, sınırlı alan ışınlaması ile tek fraksiyonda 16-19 Gy radyasyon dozunda geri dönüşümsüz hasar ya da osteonekroz bulguları tespit edilmiştir. ${ }^{47}$ Lerouksel ve ark. ${ }^{48}$, tek aşamalı 30 Gy radyasyon uyguladıkları sıçan modelinde kemik defektlerinin fibröz iyileşme paterni gösterdiklerini bildirmiştir. Buna paralel olarak, çalışmamızda tek seferde 30 Gy radyasyon dozunda Işınlama ile sıçan mandibulasında fibroatrofik kemik dokusunu taklit etmeyi amaçladık.

Literatürde, antibiyotiklerin uygulanma şekli ile ilgili farklı öneriler yer almakta ancak çenelerde görülen osteoradyonekroz gelişim profilaksisi ya da tedavisi amacıyla hangi yöntemin daha etkili ve uzun dönemli koruma sağlayacağı hakkında net veriler bulunmamaktadır. Sistemik antibiyotiklerle yapılan tedavilerde, uzun süreli ve yüksek konsantrasyonda kullanım sonucunda sistemik toksisite, miyelosüpresyon, nefrotoksisite, ilaca bağlı hepatit ve gastrointestinal yan etkiler görülmektedir. Bunların yanı sıra çenelerde osteomyelit, radyoterapi ya da ilaca bağlı osteonekroz tablosunun geliştiği durumlarda, nekrotik kemik dokularına zayıf penetrasyon göstermesi ilacın sistemik yoldan uygulanmasını kısıtlamaktadır. ${ }^{49}$ Magremanne ve ark. ${ }^{50}$, osteoradyonekroz gelişen bir hastada 6 hafta süreyle sistemik olarak antibiyotik tedavisi uygulamış ve uzun dönem kullanım sonrasında sistemik yan etkiler bildirmiştir. Buchholz ve Engelbrecht ${ }^{51}$, uzun süreli antimikrobiyal etki elde etmek ve enfeksiyonu baskılamak için kemik dolgu maddeleri içine lokal antibiyotik uygulamasını ilk kez gerçekleştirmiş ve olumlu sonuçlar bildirmiştir. Çalışmamızda, fibroatrofik fazdaki lokal enflamatuar cevabı baskılamak amacıyla 4 farklı grup antibiyotiği radyoterapiyi takiben cerrahi olarak oluşturduğumuz kemik defektlerine lokal olarak uyguladık. 
Son dönemde yapılan çalışmalarda antibiyotiklerin antienflamatuar etkilerinin olduğu ve kemik iyileşmesini destekledikleri yönünde veriler bulunmasına rağmen literatürde radyoterapi sonrasında lokal antibiyotik uygulamasının etkilerini araştıran başka bir çalışmaya rastlanmaması ve antibiyotiklerin anti-enflamatuar etkilerine yönelik hipotezlerin halen tartışlıyor olması sonuçlarımızı karşılaştırmamızı güçleştirmiştir.

\section{SONUÇ}

Çalışmada kullandığımız antibiyotiklerin antibakteriyel aktiviteden bağımsız olarak anti-enflamatuar etkinliklerinin olabileceği düşünülmektedir. Ancak, ORN profilaksisinde ya da tedavisinde etkili konservatif tedavi stratejileri konusunda günümüzde eksiklikler mevcuttur. Antibiyotikler kullanarak yapılan ön çalışmalar umut verici olsalar dahi, bu hastalık sürecinin yönetiminde farmakolojik tedavinin herhangi bir potansiyel rolünü açıklamak için ek araştırmalara intiyaç vardır. 


\section{KAYNAKLAR}

1. Ruggiero S, Gralow J, Marx RE, Hoff AO, Schubert MM, Huryn JM et al. Practical guidelines for the prevention, diagnosis, and treatment of osteonecrosis of the jaw in patients with cancer. J Oncol Pract. 2006; 2(1): 7-14.

2. Ruggiero SL, Dodson TB, Fantasia J, Goodday R, Aghaloo T, Mehrotra B et al. American Association of Oral and Maxillofacial Surgeons position paper on medicationrelated osteonecrosis of the jaw. J Oral Maxillofac Surg. 2014; 72(10): 1938-56.

3. de Souza Tolentino E, de Castro TF, Michellon FC, Passoni ACC, Ortega LJA, Iwaki LCV et al. Adjuvant therapies in the management of medication-related osteonecrosis of the jaws: Systematic review. Head Neck. 2019; 41(12): 4209-28.

4. Shuster A, Reiser V, Trejo L, lanculovici C, Kleinman S, Kaplan I. Comparison of the histopathological characteristics of osteomyelitis, medication-related osteonecrosis of the jaw, and osteoradionecrosis. Int J Oral Maxillofac Surg. 2019; 48(1): 17-22.

5. Cheriex KC, Nijhuis TH, Mureau MA. Osteoradionecrosis of the jaws: a review of conservative and surgical treatment options. J Reconstr Microsurg. 2013; 29(2): 69-76.

6. Ogawa K, Kohshi K, Ishiuchi S, Matsushita M, Yoshimi $\mathrm{N}$, Murayama $\mathrm{S}$. Old but new methods in radiation oncology: hyperbaric oxygen therapy Int $\mathrm{J}$ Clin Oncol. 2013; 18(3): 364-70.

7. Al Ruhaimi KA. Bone graft substitutes: a comparative qualitative histologic review of current osteoconductive grafting materials. Int J Oral Maxillofac Implants. 2001; 16(1): 105-14.

8. Rubin BK, Tamaoki J. Antibiotics as anti-inflammatory and immunomodulatory agents. Vol. 48. 2005: Springer Science \& Business Media.

9. Garrido-Mesa J, Rodríguez-Nogales A, Algieri F, Vezza T, Hidalgo-Garcia L, Garrido-Barros $M$ et al. Immunomodulatory tetracyclines shape the intestinal inflammatory response inducing mucosal healing and resolution. Br J Pharmacol 2018;175(23):4353-70.

10.Al-Bazie SA, Bahatheq M, Al-Ghazi M, Al-Rajhi N, Ramalingam S. Antibiotic protocol for the prevention of osteoradionecrosis following dental extractions in irradiated head and neck cancer patients: A 10 years prospective study. J Cancer Res Ther. 2016;12(2):56570.

11. Rivero JA, Shamji O, Kolokythas A. Osteoradionecrosis: a review of pathophysiology, prevention and pharmacologic management using pentoxifylline, $\alpha$-tocopherol, and clodronate. Oral Surg Oral Med Oral Pathol Oral Radiol 2017; 124(5): 464-71.

12. Sathasivam HP, Davies GR, Boyd NM. Predictive factors for osteoradionecrosis of the jaws: A retrospective study. Head \& neck 2018; 40(1): 46-54.

13. Marx RE. A new concept in the treatment of osteoradionecrosis. J Oral Maxillofac Surg 1983;41: $351-7$.
14. Withers HR, Peters LJ, Taylor JM, Owen JB, Morrison WH, Schultheiss TE et al. Late normal tissue sequelae from radiation therapy for carcinoma of the tonsil: patterns of fractionation study of radiobiology. Int $\mathrm{J}$ Radiat Oncol Biol Phys 1995; 33: 563-8.

15.Reuther T, Schuster T, Mende U, Kübler A. Osteoradionecrosis of the jaws as a side effect of radiotherapy of head and neck tumour patients - a report of a thirty year retrospective review. Int J Oral Maxillofac Surg 2003 32: 28995.

16.Grötz KA, Riesenbeck $D$, Brahm $R$, Seegenschmiedt MH, al-Nawas B, Dörr W et al. Chronic radiation effects on dental hard tissue (radiation caries). Classification and therapeutic strategies. Strahlenther Onkol 2001; 177: 96104.

17. Oh HK, Chambers MS, Martin JW, Lim HJ, Park HJ. Osteoradionecrosis of the mandible: treatment outcomes and factors influencing the progress of osteoradionecrosis. $\mathrm{J}$ Oral Maxillofac Surg 2009 67: 1378-86.

18. Reuther T, Schuster T, Mende U, Kübler A. Osteoradionecrosis of the jaws as a side effect of radiotherapy of head and neck tumour patients - a report of a thirty year retrospective review. Int J Oral Maxillofac Surg 2003; 32(3): 289-95.

19. Mendenhall WM. Mandibular osteoradionecrosis. J Clin Oncol 2004 22: 4867-8.

20.Sciubba JJ, Goldenberg D. Oral complications of radiotherapy. Lancet Oncol. 2006;7(2):17583.

21.Berger A, Bensadoun RJ. Normal tissue tolerance to external beam radiation therapy: the mandible. Cancer Radiother 2010; 4: 295300.

22.Chronopoulos A. Clinical presentation and risk factors of osteoradionecrosis (Doctoral dissertation). Available from: https://edoc.ub.uni-muenchen.de/18089/ and https://edoc.ub.uni- muenchen.de/18089/1/ Chronopoulos Aristeidis.pdf (Persistent Identifier URN $\overline{\text { : }}$ urn:nbn:de:bvb:19-180892). Accessed 15 April 2015.

23. Harris M. The conservative management of osteoradionecrosis of the mandible with ultrasound therapy. $\mathrm{Br} \mathrm{J}$ Oral Maxillofac Surg 1992; 30(5): 313-8.

24.Jereczek-Fossa BA Orecchia R. Radiotherapyinduced mandibu- lar bone complications. Cancer Treat Rev 2002; 28: 65-74. 
25. Nabil S, Samman N. Incidence and prevention of osteoradionecrosis after dental extraction in irradiated patients: a systematic review. Int J Oral Max Surg 2011; 40: 229-43.

26. Chronopoulos A, Zarra T, Ehrenfeld M, Otto S. Osteoradionecrosis of the jaws: definition, epidemiology, staging and clinical and radiological findings. A concise review. Int Dent J 2018; 68(1): 2230.

27. Nabil S, Samman N. Risk factors for osteoradionecrosis after head and neck radiation: a systematic review. Oral Surg Oral Med Oral Pathol Oral Radiol 2012; 113(1): 54-69.

28.Delanian S, Lefaix JL. The radiation-induced fibroatrophic process: therapeutic perspective via the antioxidant pathway. Radiother Oncol. 2004; 73: 11931.

29.Delanian S, Porcher R, Balla-Mekias S, Lefaix JL. Randomized,placebo-controlled trial of combined pentoxifylline and tocopherol for regression of superficial radiation-induced fibrosis. J Clin Oncol. 2003; 21: 2545-50.

30.Aviado DM, Porter JM. Pentoxifylline: a new drug for the treatment of intermittent claudication; mechanism of action, pharmacokinetics, clinical efficacy and adverse effects. Pharmacotherapy 1984;4(6): 297 307.

31.Ersoy B, Aktan B, Kilic K, Sakat MS, Sipal S. The antiinflammatory effects of erythromycin, clarithromycin, azithromycin and roxithromycin on histamine-induced otitis media with effusion in guinea pigs. J Laryngol Otol 2018; 132(7): 579-83.

32.Wax S, Piecyk M, Maritim B, Anderson P. Geldanamycin inhibits the production of inflammatory cytokines in activated macrophages by reducing the stability and translation of cytokine transcripts. Arthritis Rheum 2003; 48(2): 541-50.

33. Bisht KS, Bradbury CM, Mattson D, Kaushal A, Sowers A, Markovina S, et al. Geldanamycin and 17allylamino-17-demethoxygeldanamycin potentiate the in vitro and in vivo radiation response of cervical tumor cells via the heat shock protein 90-mediated intracellular signaling and cytotoxicity. Cancer Res 2003; 63(24): 8984-95.

34. Ianaro $A$, Ialenti $A$, Maffia $P$, Sautebin $L$, Rombolà $L$, Carnuccio $R$ et al. Anti-inflammatory activity of macrolide antibiotics. Journal of Pharmacology and Experimental Therapeutics, 2000; 292(1): 156-63.

35.Yrjänheikki J, Tikka T, Keinänen R, Goldsteins G, Chan $\mathrm{PH}$, Koistinaho J. A tetracycline derivative, minocycline, reduces inflammation and protects against focal cerebral ischemia with a wide therapeutic window. Proc Natl Acad Sci 1999; 96(23): 13496-500.

36. Shapira L, Soskolne WA, Houri Y, Barak V, Halabi A, Stabholz A. Protection against endotoxic shock and lipopolysaccharide-induced local inflammation by tetracycline: correlation with inhibition of cytokine secretion. Infect Immun 1996; 64(3): 825-8.
37.Norden CW, Wentzel H, Keleti E. Comparison of techniques for measurement of in vitro antibiotic synergism. J Infect Dis 1979; 140(4): 629-33

38. Curis E, Pestre V, Jullien V, Eyrolle L, Archambeau D, Morand $\mathrm{P}$ et al. Pharmacokinetic variability of clindamycin and influence of rifampicin on clindamycin concentration in patients with bone and joint infections. Infection 2015; 43(4): 473-81.

39.Zeller V, Dzeing-Ella A, Kitzis MD, Ziza JM, Mamoudy $P$, Desplaces N. Continuous clindamycin infusion, an innovative approach to treating bone and joint infections. Antimicrob Agents Chemother. 2010; 54(1): 88-92.

40.Taha Ö. Histomorphometric and radiologic evaluation of local alendronate administration on experimental bone defect healing. Thesis in Oral Surgery Ankara: Hacettepe University Institue of Health Science, Ph.D.; 2017.

41.Rice N, Polyzois I, Ekanayake K, Omer O, Stassen LF. The management of osteoradionecrosis of the jaws-a review. Surgeon. 2015; 13(2): 101-9.

42. Reuther $T$, Schuster $T$, Mende $U$, Kübler A. Osteoradionecrosis of the jaws as a side effect of radiotherapy of head and neck tumour patients a report of a thirty year retrospective review. Int $\mathrm{J}$ Oral Maxillofac Surg. 2003; 32(3): 289-95.

43. Glanzmann C, Grätz KW. Radionecrosis of the mandibula: a retrospective analysis of the incidence and risk factors. Radiother Oncol 1995; 36(2): 94100.

44.Semrau R, Mueller RP, Stuetzer H, Staar S, Schroeder U, Guntinas-Lichius $O$ et al. Efficacy of intensified hyperfractionated and accelerated radiotherapy and concurrent chemotherapy with carboplatin and 5-fluorouracil: updated results of a randomized multicentric trial in advanced head-andneck cancer. Int J Radiat Oncol Biol Phys. 2006; 64(5): 1308-16.

45.Donneys A, Nelson NS, Page EE, Deshpande SS, Felice PA, Tchanque-Fossuo $\mathrm{CN}$ et al. Targeting angiogenesis as a therapeutic means to reinforce osteocyte survival and prevent nonunions in the aftermath of radiotherapy. Head \& neck 2015; 37(9): 1261-7.

46. Batista JD, Zanetta-Barbosa D, Cardoso SV, Dechichi P, Rocha FS, Pagnoncelli RM. Effect of lowlevel laser therapy on repair of the bone compromised by radiotherapy. Lasers Med Sci. 2014; 29(6): 1913-8.

47.Arnold M, Stas P, Kummermehr J, Schultz-Hector S, Trott KR. Radiation-induced impairment of bone healing in the rat femur: Effects of radiation dose, sequence and interval between surgery and irradiation. Radiother Oncol. 1998; 48(3): 259-65.

48. Lerouxel E, Moreau A, Bouler JM, Giumelli B, Daculsi $G$, Weiss $P$ et al. Effects of high doses of ionising radiation on bone in rats: A new model for evaluation of bone engineering. Br J Oral Maxillofac Surg. 2009; 
49. Grisar K, Schol M, Schoenaers J, Dormaar T, Coropciuc R, Vander Poorten V et al. Osteoradionecrosis and medication related osteonecrosis of the jaw: similarities and differences. Int J Oral Maxillofac Surg. 2016; 45(12): 1592-9.

50. Magremanne M, Picheca S, Reychler H. Etiologic diagnosis of jaw osteonecrosis, other than bisphosphonate and radiotherapy related osteonecrosis. Rev Stomatol Chir Maxillofac Chir Orale 2014; 115(1): 45-50.

51.Buchholz HW, Engelbrecht $\mathrm{H}$. Depot effects of various antibiotics mixed with Palacos resins. Chirurg 1970;41(11): 511-5.

Yazışma Adresi:

Dr. Öğr. Üyesi Özge DOĞANAY

Bezmialem Vakıf Üniversitesi

Diş Hekimliği Fakültesi

Ağız, Diş ve Çene Cerrahisi AD

Fatih, İstanbul, Türkiye

Tel : : +90 5301793971

E Posta: ozgedoganay87@gmail.com 